\title{
PATENT INFRINGEMENT BY THE GOVERNMENT
}

\section{KarL FEnNing}

From almost the beginning our government has used mechanical devices, particularly in its army and navy and in its various clerical operations. As the government has expanded in its multitudinous activities it has used a very greatly increased number of mechanical contrivances of various sorts. Since the ingenuity of the inventor extends to every field of industry and art, it is not surprising to find that the government has made. purchased, and used a great variety of inventions, many of which are covered by valid patents. The large monetary value of the patented articles purchased and used by the government during the war naturally caused the owners of patents covering such devices ardently to press the government for compensation for the use of the patented inventions. Immediately after the war, various boards were organized to investigate the matter and award compensation to inventors. Among others, the Munitions Patent Board in the War Department considered many claims and made some awards. Likewise, a joint board devoted many days to an investigation and analysis of a great mass of patents relating to radio which were alleged to be infringed by the government. Funds, however, were not made available to pay the awards, and the claimants were relegated to litigation for compensation.

The importance of some of the litigation to both the government and the owners of the patent may be seen from the character of some of the claims. In Brodie v. United States ${ }^{2}$ the inventor claimed that every metal hat furnished to the soldiers during the war infringed his patent. There are several suits now pending which demand compensation for inventions used in every aeroplane used by the government.

In addition to litigation in various District Courts, and other claims which may be settled by negotiation, there are now pending in the Court of Claims between forty and fifty patent cases. About a third of these make no specific allegation as to the monetary recovery expected, but in the other cases claims are made to the extent of nearly six hundred million dollars.

The government of the United States has the immunity of the sovereign from suit, and for many years there was no means of procuring redress from it for its use of patented inventions. In the early days, suits were brought against individual officers or

I 62 Ct. Cl. 29 (1926). 
employees of the government and sometimes against groups of them. One of those suits was the case of Bellinap v. Schild." There the owners of the patent brought suit against the government officers and employees who had constructed and were using caisson gates at a government navy yard. The suit was the usual equity suit for infringement of a patent, asking an injunction against the defendants' continuing the use of the caisson gate and an accounting of their profits. The Supreme Court, however, held that it would look through the form to the substance and that in essentials the use was purely for governmental purposes. An injunction could not be issued restraining the government officers and employees from continuing the government use, since such action would, in effect, be a restraining of the government itself. The court then took up the matter of profits and found that the only profits involved in the manufacture and operation of the alleged infringing device were profits which accrued, not to the individuals sued, but to the government itself, and, consequently, could not be recovered from the officers and employees sued. That continued to be the state of the law with respect to infringement suits until 1910, when permission to bring infringement suits against the government itself in the Court of Claims was granted by Congress. Belknap v. Schild established the law with respect to suing a government employee for a governmental act.

Where, however, the government procured a contractor to manufacture and furnish to it devices infringing a patent, or when it procured a government contractor to use a patented invention in carrying out a government contract, there was a right against the contractor for an injunction against infringement of the patent and an accounting of profits made in so infringing, and some cases were brought on this theory.

There were, of course, cases in which contracts were entered into by government officials for the use of patented inventions, the government agreeing either positively or by implication to compensate the inventor for the use of his invention. Since Congress in 1887 had given to the Court of Claims, under the Tucker Act, ${ }^{3}$ concurrent jurisdiction with the United States courts of suits against the government upon any contract, express or implied, with the government of the United States, it was possible to recover in such case for the government infringement of the patent. This, however, was strictly limited to actions based on contracts, and did not give the right to sue for simple tortious infringement. The Tucker Act specifically limited the jurisdiction of the courts in suits against the gov-

2161 U. S. 10, 16 Sup. Ct. 443 (1896).

${ }^{3}$ Now Judicial Code $\S 145$ [U. S. Comp. Stat. (1916) § 1136]. 
ernment to "cases not sounding in tort." In the case of Russell $v$. United, States, the Supreme Court very clearly established that in order to give the Court of Claims jurisdiction under the Tucker Act, the demand sued on must be founded on "a convention between the parties-a coming together of minds." The Supreme Court, therefore, excluded as not meeting this condition, those contracts or obligations that the law is said to imply from a tort such as the infringement of a patent. To similar intent are Schillinger v. United, States ${ }^{5}$ and United States v. Bcrdan Fire Arms Company. ${ }^{6}$ In United States v. Bcthlekem Steel Company, ${ }^{7}$ relating to armor plate, the Supreme Court affirmed the Court of Claims in holding that where the government uses a patented invention knowingly with the consent and express permission of the owner, and does not repudiate the title of such owner, a contract to pay for its use on a quantum meruit basis will be implied.

The law was in this condition when, on June 25, 1910, the President approved an act "to provide additional protection for owners of patents of the United States, and for other purposes." 8 This law on its face provides for the bringing of infringement suits against the government even when there is no contract. In the case of Crozier v. Krupp ${ }^{9}$ a suit for infringement had been brought against a government officer in the Supreme Court of the District of Columbia, where the bill was dismissed on demurrer. The Supreme Court affirmed this decision, holding that if the right to an injunction against a government officer had ever existed, it was taken away by the Act of 1910 which, in effect, gave the government the right to use inventions, and thus

1182 U. S. 516 (1901).

5155 U. S. 163, 15 Sup. Ct. 85 (1894).

6 156 U. S. 552, 15 Sup. Ct. 420 (1895).

7258 U. S. 321, 42 Sup. Ct. 334 (1922).

$s$ "Whenever an invention described in and covered by a patent of the United States shall hereafter be used by the United States without license of the owner thereof or lawful right to use the same, such owner may recover reasonable compensation for such use by suit in the Court of Claims: Provided, however, That said Court of Claims shall not entertain a suit or award compensation under the provisions of this act where the claim for compensation is based on the use by the United States of any article heretofore owned, leased, used by, or in the possession of the United States: Provided further, That in any such suit the United States may avail itself of any and all defenses, general or special, which might be pleaded by a defendant in an action for infringement, as set forth in Title Sixty of the Revised Statutes, or otherwise: And provided further, That the benefits of this act shall not inure to any patentee who, when he makes such claim, is in the employment or service of the Government of the United States, or the assignee of any such patentee; nor shall this act apply to any device discovered or invented by such employee during the time of his employment or service." U. S. Comp. Stat. (1916) § 9465.

9 224 U. S. 290, 32 Sup. Ct. 488 (1912). 
gave a license to government officers to use them. The court said that the Act of 1910

"makes full and adequate provision for the exercise of the power of eminent domain for which considered in its final analysis it was the purpose of the statute to provide. . . . In other words, the situation prior to the passage of the Act of 1910 was this: When it was asserted that an officer of the Government had infringed a patent right belonging to another,in other words, had taken his property for the benefit of the Government,- the power to sue the United States for redress did not obtain unless from the proof it was established that a contract to pay could be implied - this is to say, that no right of action existed against the United States for a mere act of wrongdoing by its officers."

After noting the title of the Act of 1910, "to provide additional protection for owners of patents," the court held that

"the statute adds to the right to sue the United States in the Court of Claims, already conferred when contract relations exist, the right to sue for patent infringement even although no element of contract is present."

Thus it seemed that, under the Act of 1910, the government was free to go ahead without court disturbance, and it was assumed that government contractors were placed in the same position as government employees. Much of the greatly expanded war activities of the government were entered into with this assumption. A decision of the Supreme Court, however, in Cramp \& Sons v. Curtis Turbine Co., ${ }^{10}$ showed that the Act of 1910 was not as far reaching as the government and the government contractors had hoped. Cramp, after the Act of 1910 and under contract with the government, built boats fitted with a device which was held to be an infringement of the Curtis patents. It was clear that the Curtis Company might have sued the government to recover compensation for the use of the infringing devices. Instead of pursuing that course, however, the Curtis Company sued Cramp for infringement of the patent and demanded an accounting of the profits Cramp had made under his government contract. The Supreme Court said:

\footnotetext{
"A contractor with the United States, therefore, is in the very nature of things bound to discharge the obligation of his contract without violating the rights of others, and merely because he contracts with the United States is not vested with the power to take the property of others upon the assumption that as a result of the contract with the United States he enjoys the right to exercise public and Governmental powers possessed by the United States."
}

10246 U. S. 28, 38 Sup. Ct. 271 (1918). 
The court then held that the Act of 1910 did not effect a license to the United States or the contractor making the patented device to make or use the invention, and that the contractor could be sued for infringement and enjoined in spite of the operation of that act. That decision was handed down in March, 1918, and in April, 1918, the Acting Secretary of the Navy wrote a letter to the Chairman of the Committee on Naval Affairs of the Senate, calling attention to the fact that manufacturers might be enjoined from supplying to the government devices needed for the prosecution of the war, and asking that Congress do something to relieve the situation. Under the war stress, Congress acted with unusual speed and the Naval Appropriation Act of July 1, 1918, included an amended Act of 1910, the first clause of which reads:

"Whenever an invention described in and covered by a patent of the United States, shall hereafter be used or manufacturicd by or for the United States without license of the owner thereof, or lawful right to use or manufacture the same, such owner's remedy shall be by suit against the United. States in the Conrt of Claims for the recovery of his reasonable and cntire compensation for such use and, manufacture." ${ }^{10 a}$

For convenience I have emphasized the new portion of the law, which continued with the proviso clauses of the Act of 1910 without substantial change. The effect of this act has been recently considered by Chief Justice Taft in a decision handed down January 3, 1928 in Richmond Screw Anchor Co. v. United States, ${ }^{10 b}$ where he says:

"The purpose of the amendment was to relieve the contractor. entirely from liability of every kind for the infringement of patents in manufacturing anything for the Government and to limit the owner of the patent and his assigns and all claiming through or under him to suit against the United States in the Court of Claims for the recovery of his reasonable and entire compensation for such use and manufacture. The word 'entire' emphasizes the exclusive and comprehensive character of the remedy provided. As the Solicitor General says in his brief with respect to the Act, it is more than a waiver of immunity and effects an assumption of liability by the Government."

It seems fairly clear, then, that the only recovery for an infringement by or for the government must be in the Court of Claims in a suit brought directly against the government, which probably will be required to pay to the patent owner the profits made by the contractor.

The importance of this jurisdiction is emphasized by the fact that since the passage of the Appeals Act of February 13, 1925,

I0a U. S. Comp. Stat. (Supp. 1919) §9465.

$10 \mathrm{~b} 48$ Sup. Ct. 194 (1928). 
there has been no right of appeal to the Supreme Court; the Court of Claims being about the only trial court in the United States from which no appeal may be taken. Of course there remains the seldom granted petition for certiorari to the Supreme Court. The Court of Claims in interpreting its jurisdiction is highly technical, and insists that under the Act of 1918 it has jurisdiction of the government alone as defendant. In Waite $v$. United States ${ }^{11}$ the Court of Claims announced this theory in refusing to allow the intervention as defendant, along with the United States, of the Wappler Electric Company, which had manufactured the alleged infringing devices for the government and in its contract had agreed to hold the government harmless for patent infringement. It may be noted, in passing, that the Court of Claims had interpreted the expression "hold harmless" as against the government to include all the expenses of the suit, including attorneys' fees, in Winchester Repeating Arms Co. $v$. United States.12 Presumably the same holding would be made in favor of the government, and the "holding harmless" contractor would be called upon to pay not merely what the petitioner recovers but the entire expense of the suit.

U. S. Rev. Stat. (1873) $§ 3477$ in general terms provides that an unliquidated claim against the government may not be assigned, and it was assumed that this section of the statute applied to a claim of infringement against the government. Such was the holding of the Supreme Court under the Act of 1910 in Brothers $v$. United States. ${ }^{13}$ The suit there was on an expired patent brought by an assignee who had owned the patent only two and one half months, prior to the date the patent expired. The court said:

"His claim to compensation is necessarily limited to this brief period, since there could be no assignment to him of any unliquidated claim against the Government arising prior to the time he became the owner of the patent."

The government has rested on this as a proper interpretation of the law and the Court of Claims has acted on it. On January 3, 1928, however, Chief Justice Taft, in Richmond Screw Anchor Co.v. United States, ${ }^{23 a}$ handed down an opinion for the Supreme Court distinguishing between the Act of 1910 and the amendatory Act of July 1, 1918 with respect to assignments of claims. In that case the petitioner had an assignment covering all rights for past infringement of the patent for a loading beam used by the government. The Chief Justice, pointed out that prior to the

\footnotetext{
1157 Ct. Cl. 546 (1922).

1251 Ct. Cl. 118 (1916).

13250 U. S. 88, 39 Sup. Ct. 426 (1919).

13a Supra note 10b.
} 
Act of 1918 such assignment would have enabled the petitioner to recover from the contractor for all his infringement and that when the government, by the Act of 1918, put itself in the place of the contractor by assuming all his liabilities because of infringement, a serious question as to the constitutionality of the Act of 1918 would be raised unless the patent owner were allowed to assign his claim against the government. He therefore held that

"section 3477 does not apply to the assignment of a claim against the United States which is created by the Act of 1918 insofar as the Act deprives the owner of the patent of a remedy thereof and makes the Government indemnitor for its manufacturer or contractor in his infringements."

The doctrine that the government contractor is not liable for patent infringement even under the Act of 1918 has its limitations. In the case of Wood v. the Atlantic Gulf \& Pacific Co." suit was brought by a patent owner against a contractor dredging a harbor for the Government. The alleged infringing device was a dredging machine being used by the contractor, who endeavored to avoid liability and have the bill dismissed on the ground that the only right of recorery was against the government under the Act of 1918. The court, however, refused to dismiss the bill, holding the contractor independently liable on the theory that the government did not prescribe the particular type of dredge to be used but left the contractor free to use it or not. It seems good law to say that the gorernment is responsible only for the specific things which it directs to be done and that the contractor only is liable for the use of devices which he independently elects to use. It is obviously foolish to hold the government liable for the use of a patented machine for manufacturing ordinary rubber bands merely because it purchases rubber bands from the infringer, when it is a matter of complete indifference to the government how the rubber bands are made.

In the case of Foundation Co. v. Linderpinining \& Foundation Co., ${ }^{15}$ the court refused a preliminary injunction against the Government contractor in view of the Act of 1918. In Sperry Gyroscope Co. v. Arma Engineering Co., ${ }^{26}$ however, the Supreme Court sent back to the District Court a case brought against a government contractor which had been dismissed for lack of jurisdiction in view of the Act of 1918, with directions to take jurisdiction and determine whether the acts complained of were necessarily directed and controlled by the government. When a manufacturer has made infringing devices for the govern-

\footnotetext{
14296 Fed. 718 (S. D. Ala. 1924).

15256 Fed. 374 (S. D. N. Y. 1919).

16271 U. S. 232, 46 Sup. Ct. 505 (1926).
} 
ment but has also made similar devices for private sale, the court held, in Floyd Smith Co. v. Irving Air Chute Co., ${ }^{17}$ that suit might be maintained in the District Court for an injunction against manufacture for private sale and to recover profits and damages for such private sale. An injunction when issued need not specifically exclude manufacture for the government, since such manufacture is protected by the Act of 1918 itself.

One of the idiosyncrasies of practice in the Court of Claims in patent suits is the holding in Richmond, Screw Anchor Co. v. Umited States ${ }^{18}$ that the Government need not set up in its answer or give thirty days' notice of its defenses as required by U. S. Rev. Stat. (1873) $\S 4920$ of other defendants in patent infringement suits. The court bases this upon its interpretation of the Act of 1918 that the "United States may avail itself of any and all defenses, general or specific, that might be pleaded by a defendant in an action for infringement as set forth in Title Sixty of the Revised Statutes, or otherwise." The theory of the court is that defenses which others may plead accrue to the government without pleading. In patent suits in the Court of Claims, as in other suits, the government merely files a formal general traverse leaving the petitioner in entire ignorance of what defense he will have to meet until the defense testimony is adduced. This puts the owner of the patent at a disadvantage and frequently needlessly enlarges the record and delays the trial.

During the war the army and navy believed that secrecy should be enforced in reference to inventions which might be useful to the government in the prosecution of the war and which might likewise be useful to their enemies in their activities against the government. It was therefore proposed to Congress to pass an act by which inventors would be required to keep secret their inventions and at the same time to allow the Patent Office to delay the issuance of a patent which might disclose the invention. It was seen that it was inequitable to use the information of any inventor without giving him compensation. Likewise, it was seen that no recovery could be obtained before issuance of the patent. By withholding the patent the government could thus avoid all liability to pay compensation to the inventor. There was, therefore, included in the Trading with the Enemy Act a section which provided that the President might order an invention held secret and the patent withheld from issue. This gave to the inventor the right to sue in the Court of Claims when the patent was finally issued for any governmental use of the invention before the issuance of the pat-

17276 Fed. 834 (W. D. N. Y. 1921).

1858 Ct. Cl. 433 (1923). 
ent. The Trading with the Enemy Act was approved October 6,1917 , and on the same day there was approved a separate law ${ }^{19}$ substantially the same in wording as the section in the Trading with the Enemy Act referred to, but providing that the Commissioner of Patents rather than the President should issue the secrecy order. The President delegated his authority to the Federal Trade Commission and thereafter secrecy orders were issued in a great many patent applications by the Federal Trade Commission or by the Commissioner of Patents and, with respect to some applications, by both. Because these orders held the applications in the Patent Office, the Act of 1917 became familiarly known as the Cold Storage Act. A few suits have been instituted under this act in the Court of Claims but as yet only one case has been decided and that case has not been taken up to the Supreme Court. Under no other law may suit be brought against any defendant for infringement of a patent by an act committed before the issuance of the patent.

The case of Zeidler $v$. United States ${ }^{\circ}$ was one in which there was involved a patent, the application for which had had applied to it the secrecy order provided for by the Act of 1917. A company largely owned by Zeidler, the inventor, had a subcontract to make parts of shells for government contractors. He disclosed his invention to his company, to the government contractors, and to government employees, and his invention was put into production by his company. He then filed his application and the secrecy order was issued. There was no formal tender of the invention to the government other than suggesting to the main contractor the substitution of the patented device

19 "Whenever during a time when the United States is at war the publication of an invention by the granting of a patent might, in the opinion of the Commissioner of Patents, be detrimental to the public safety or defense or might assist the enemy or endanger the successful prosecution of the war he may order that the invention be kept secret and withhold the grant of a patent until the termination of the war; Provided, That the invention disclosed in the application for said patent may be held abandoned upon it being established before or by the commissioner that in violation of said order invention has been published or that an application for a patent therefor has been filed in a foreign country by the inventor or his assigns or legal representatives, without the consent or approval of the Commissioner of Patents, or under a license of the Secretary of Commerce as provided by law.

"When an applicant whose patent is withheld as herein provided and who faithfully obeys the order of the Commissioner of Patents above referred to shall tender his invention to the Government of the United States for its use, he shall, if and when he ultimately receives a patent, have the right to sue for compensation in the Court of Claims, such right to compensation to begin from the date of the use of the invention by the Gorernment." U. S. Comp. Stat. (Supp. 1919) § 9429a.

${ }^{20} 61$ Ct. Cl. 537 (1926). 
for another device, which substitution was approved by the government. The court held that the invention had not been properly kept secret under the statute and that there had been no tender and acceptance by the government, and consequently Zeidler had no right under the Act of 1917.

Unlike the Act of 1918, the Act of 1917 does not, in terms, reserve to the United States the usual defenses of a defendant in an infringement suit, and in the Zeidler case, counsel for the petitioner urged that no defense of invalidity of the patent could be raised by the government. The court, however, overruled this and applied the prior act to the patent and found it invalid.

In addition to the cases in the Court of Claims covered by the general laws considered above, there have been a number of instances where owners of patents have gone before Congress and procured special acts giving them the right to sue the government for the use of inventions covered by their patents. In some instances these cases have been brought in the Court of Claims, and in some instances they have been brought in the United States district courts when allowed by the special act. Each such case, of course, is a law unto itself and contains nothing of general interest.

The ambition of inventors in the employ of the government very early caused them to institute suit against the government or government officials for infringement of their patents. It was, of course, recognized that the mere fact that an inventor was in the employ of the government did not give the government title to his inventions, and that the patent relations between the government and its employees are like that of other employers and employees. In Solomons $v$. United States ${ }^{21}$ the court said :

"The Government has no more power to appropriate a man's property invested in a patent than it has to take his property invested in real estate; nor does the mere fact that an inventor is, at the time of his invention, in the employ of the Government transfer to it any title to, or interest in it. An employee, performing all the duties assigned to him in his department of service, may exercise his inventive faculties in any direction he chooses, with the assurance that whatever invention he may thus conceive and perfect is his individual property. There is no difference between the Government and any other employer in this respect."

The court proceeded to hold that if the inventor is employed to do special work the result belongs to the employer and when he invents along the line. of his work and perfects it at the employer's expense, and allows the employer the use of it with-

${ }^{21} 137$ U. S. $342,346,11$ Sup. Ct. 88,89 (1890). 
out protest, a license, or shop right, accrues to the government. In Gill $v$. United States ${ }^{22}$ the suit was on a patent of a government employee, who conceived and developed the invention out of hours, but let the government make his machines. The court said that

"whether the property of the Government and the services of its employees be used in the experiments necessary to develop the invention or in the preparation of the patterns and working drawings and the construction of the completed machines, is of no importance."

There are, however, cases where government employees have been promised compensation for an invention and have received the compensation. It will be noted, however, that both the Act of 1910 and the Act of 1918 specifically preclude suits by one who is a government employee, either at the time he makes the claim or at the time he makes the invention, and it is possible that the Court of Claims, in line with the Zeidler case, will so interpret the Act of 1917.

Since 1883 there has been on the statute books provision for issuing to officers of the government patents without fees,

"provided that the applicant in his application shall state that the invention described therein, if patented may be used by the Government or any of its officers or employees in prosecution of work for the Government, or by any other per'son in the United States, without the payment to him of any royalty thereon, which stipulation shall be included in the patent."

The only time such a patent, issued without fees, has been before the courts was in the case of Squire v. American Tel.\& Tel. Co., ${ }^{23}$ where the patentee was held bound not merely by the statute but was actually estopped by statements made to the defendant that he would not demand compensation for infringement. In view of the uncertainty as to how this statute will be finally interpreted and because no one knows just what are the rights of the inventor with such a patent, the various government departments are unable to reach a uniform practice with respect to patents of their employees. There has been an Interdepartmental Patent Board working on the problem for some years. Some departments require inventors in their employ to file applications for patents under the Act of 1883 . Other's require inventors in their employ to file applications procured at government expense in consideration of a license to the government, reserving to the inventor all of his commercial rights. In some instances these commercial rights very materially augment the government compensation so that the government is enabled to keep in its employ men whom it might not otherwise afford.

22160 U. S. 426, 16 Sup. Ct. 322 (1896).

237 F. (2d) 831 (C. C. A. 2d, 1925). 